Marijana Seočanac ${ }^{1}$

University of Kragujevac

Faculty of Hotel Management and Tourism

in Vrnjačka Banja
P. 29-38

SCIENTIFIC REVIEW ARTICLE doi:10.5937/ESD1902029S

Received: September, 06, 2019

Accepted: November, 01, 2019

\title{
ARE LOHAS CONSUMERS A PERSPECTIVE TOURISM SEGMENT? ${ }^{2}$
}

\begin{abstract}
In most social communities today, issues such as sustainability, ecology and the environment are becoming increasingly important. Consumers are no longer considering just the impact that their choices have on themselves, but are increasingly considering the impact their choices have on the environment. For this reason, significant attention is being paid to organically produced products, unpolluted areas and suppliers that adhere to good sustainability practices. This trend of life has led to the creation of a consumer group that incorporates sustainable behavior into all aspects of life (LOHAS). The aim of this paper is to examine the characteristics of this market group through a review of the existing literature, as well as to determine if LOHAS consumers represent a promising segment when it comes to tourism.
\end{abstract}

Key words: LOHAS, sustainability, lifestyle, green consumers, tourism

JEL classification: Z32, Q51

\section{ДА ЛИ СУ LOHАS ПОТРОШАЧИ ПЕРСПЕКТИВАН ТУРИСТИЧКИ СЕГМЕНТ?}

\section{Апстракт}

У већини данашюих друштвених заједница питана попут одрживости, екопогије и заштите животне средине, постају све важнија. Потрошачи више не разматрају само утииај сопственог избора по них саме, већ све више разматрају и какав утиизај юихов избор има на околину. Из тог разлога, све већа пажна поклана се органски произведеним производима, незагађеним подручјима и добављачима који се придржавају добре праксе у области одрживости. Овакав тренд живота резултирао је стваранем групе потрочача која одрживо понашаюе уктучују у све аспекте живота (LOHAS). Циъ овог рада је да се кроз преглед постојеће литературе истраже карактеристике ове тржишне групе, као и да се утврди да ли LOHAS потрошачи представљају перспективан сегмент када је у питану туризам.

Клучне речи: LOHAS, одрживост, стил живота, зелени потрочачи, тури$3 a \mathcal{M}$

\footnotetext{
${ }^{1}$ marijanaseocanac@gmail.com

${ }^{2}$ The paper is part of the Project No. 179066, funded by the Ministry of Education, Science and Technological Development of the Republic of Serbia.
} 


\section{Introduction}

Population growth and increasing consumption affects the increased use of natural resources and an increase of harmful effects on the environment (Ivanović, Gašić, Peric \& Krulj - Mladenovic, 2016). Precisely because of that influence the need for sustainable development emerges as the central thought of many people who undertake various activities to actively contribute to the preservation of the environment.

The issue of environmental sustainability contributes to the appearance of consumers who are interested in sustainable products rather than conventional products because the use of such products, and they as individual persons, can contribute to solving he common problem. As the time was passing, these individuals were singled out from the mass of other consumers, and to enable their easier identification there has been created an acronym - LOHAS.

LOHAS concept, the acronym for Lifestyles of Health and Sustainability (Ray \& Anderson, 2000), includes everything from organic food and body care to socially responsible investing, alternative medicine, eco-tourism, renewable energy and energyefficient cars and appliances (Font \& Epler Wood, 2007; Ulrich, 2015). The term also describes a group of consumers who wants to do business with companies they share the same interests and priorities in these areas (Urh, 2015).

LOHAS concept is based on the extensive research undertaken in the United States in the mid nineties of the last century by sociologist Paul Ray who found out that nearly $25 \%$ of the U.S. population identified the concepts of health, sustainability and social justice as major elements forming their world view and how they chose to live their lives. Ray called this group the "Cultural Creatives" and described them as innovators and leaders of cultural change, voracious consumers of art and books and also major drivers of a type of consumption that demonstrated a recognition of individual and community impact. However, at the time of Ray's early work, there was little broad recognition of the true size and power of this cultural phenomenon as it was difficult to define from a market perspective (Ray \& Anderson, 2000; Baker \& Bez, 2007).

The term LOHAS was introduced by market research institute - Natural Marketing Institute (NMI). Furthermore, the concept of LOHAS has turned from the cultural group into a new consumer group, whose market potential is estimated at 200 billion US dollars for the year 2004 (Kreeb, Motzer, \& Schulz, 2009). Many market institutions have directed their efforts towards attracting this market segment, seeing it as a new marketing and production opportunities (Heim, 2011).

The aim of this work is, firstly by reviewing of the existing literature, to explore all the characteristics of this group of consumers and their lifestyles. Then, to determine what percentage of the population belongs to the LOHAS and what are the values these consumers are directed to. Last, based on the literature reviewed, it is to determine whether LOHAS consumers represent a promising segment when it comes to tourism.

\section{Characteristics of LOHAS consumers}

There can be found different definitions of LOHAS consumers in the literature. By Pesek, Helton \& Nair (2006) LOHAS consumers are defined as those who value holistic 
health, the environment, global social justice, personal development and sustainable living. Urh (2015) added that LOHAS consumers are "those who are passionate about the environment, the planet, social issues, health, about human rights, fair trade, sustainable practices, and peace, spiritual and personal development" (p. 167). Ergüven \& Yilmaz (2016) in their study describes LOHAS consumers as the kind of consumer who wants to improve the health and sustainability with their consuming behavior. They consume products and services only if they are not unhealthy and harmful to the environment. They advocate a healthy and conscious lifestyle and care about whether the products or services they consume are produced under acceptable conditions. Schüpbach, Grolle, Dauwalder, and Amhof (2008) point out that this group of consumers is characterized by focusing on conscientious consumption of products in order to contribute to the health, social justice, sustainability and ecology. The Future Institute in Germany defines LOHAS consumers as follows: "LOHAS cannot be fixed to the age, nor to a social stratum, are neither neo-alternatives nor Greenies. More importantly, they represent the first and only sustainable global lifestyle" (Ergüven \& Yilmaz, 2016, p. 268). In all these definitions, nature, environment and social standards, appear as components that are very important for LOHAS consumers.

Research by the German Future Institute (Das Zukunftsinstitut) has highlighted another important characteristic of this consumer group and that is a "ybrid" lifestyle (Aue, 2008). It can be seen in Figure 1 that "eing LOHAS means, for example, being in favor of technical developments while enjoying nature, living a self-centered life while thinking about others and being realistic while open to spiritual ideas" (Urh, 2015, p. 169) .

Figure 1: LOHAS consumer characteristics

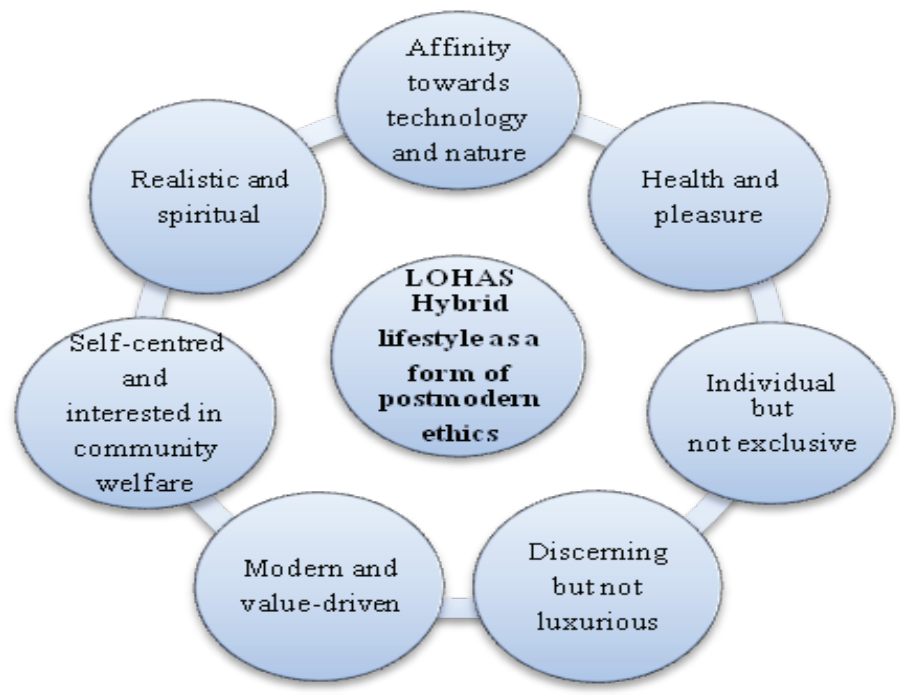

Source: Urh, B. (2015, p. 169), adapted by the author

The researches have shown that there is no clear socio - demographic group that can be considered as LOHAS and many studies have shown that some correlations are even 
contradictory (Urh, 2015). Professional service company Ernst \& Young has conducted a survey on consumer concerns about health and sustainability issues, which has involved more than 3,000 people in Austria, Switzerland, the Netherlands and Germany. According to the results of a research, $44 \%$ of participants stated that they would pay up to $20 \%$ more for an "organic" product rather than a product manufactured under standard procedures (Schüpbach et al., 2008). This shows that LOHAS people do not have strict rules, such as giving up on something while maintaining their lifestyles, and that the costliness of a product does not affect their consuming behaviors (Ergüven \& Yilmaz, 2016). The study also found that LOHAS consumers are appearing at all demographic levels, and being a LOHAS group does not mean that people are rich or of a certain age or gender. Urh (2015) stated that "although they are not a homogeneous group of consumers, LOHAS share some certain characteristics, for example, that they mainly live in urban areas" (p. 168). The results of a study conducted by the Institute of Natural Marketing (NMI) (2008) showed that the typical LOHAS consumer is a middle-aged married woman who, in most cases, has no children. Also, this research concluded that LOHAS consumers generally have university degrees and are well paid.

In order to discover the priorities and way of thinking of LOHAS consumers, Ergüven \& Yilmaz (2016) in their work summarized the results of various surveys conducted after 2000. The data collected showed that LOHAS consumers (Ergüven \& Yilmaz, 2016, p. 268):

- Are between the ages of 20 and 90,

- Cannot be identified with a single social stratum,

- Are looking for quality,

- Are in the high-income group,

- Have traveling experience,

- Have higher educational levels,

- Advocate health and sustainability,

- Are environment- and longevity-conscious,

- Prefer an individually-determined lifestyle.

However, LOHAS consumers are difficult to be described based on demographic characteristics such as gender, age, qualifications and income (Szakály et al., 2017). Instead, people who rely on the LOHAS principle are typically described in terms of psychological characteristics: it is a broad group characterized by similar values, concerns, and priorities that they share, as well as the criteria they use in purchasing, investing, and lifestyle decisions (Headwaters MB, 2016). More than anything, what distinguishes LOHAS members from non-LOHAS individuals is a permanent interest in integrating their values in many areas of their lives (Urh, 2015).

\section{LOHAS consumer values}

Grunert \& Juhl (1995) pointed out that the choice of values helps to make different decisions, and therefore the values represent the characteristics of a person or group of consumers, and therefore can play a very important role in the study of consumer behavior. The results of a study conducted by Buerke, Straatmann, Lin-Hi, and Müller 
(2017) showed that consumer awareness and value based on sustainability have a positive impact on responsible consumer behavior.

Values such as a responsibility, credibility, and sustainability are the main principles that the LOHAS adhere to in all life circumstances. LOHAS consumers tend to make their purchasing decisions in accordance with their own values of social and environmental responsibility (Urh, 2015). Their commitment to sustainability is seen in the purchase of socially responsible and environmentally friendly products (Szakály et al. 2017). For them, it is more important to consume sustainably than excessively. LOHAS people adopt this type of consumption in all aspects of their lives and their consumption habits, from eating, health, through transportation, technology, economics, clothing, cosmetics, holidays, sports and more (Ergüven \& Yilmaz, 2016).

Szakály et al. (2017), in their study, pointed out five value categories that stood out after analyzing the results of various research related to LOHAS consumers, such as: authentic values, health-conscious values, ethical values, individualist value and environmentalconscious values (p. 3). They point out that authentic values are primarily expressed in the search for local and home made products. The LOHAS people prefer food products, which are locally and seasonably grown, and which do not include carbon footprints in production, storage and transportation stages, (Ergüven \& Yilmaz, 2016). Health awareness is manifested through a healthy lifestyle, and environmental awareness is associated with a sustainable lifestyle, which includes a commitment to environmental protection (Szakály et al., 2017). The annual survey of LOHAS behavior conducted by the Institute of Natural Marketing (NMI) found that consumers buy green products, eat organic foods, or use renewable energy, largely due to the fact that they perceive their personal health as a driver who reduces the impact on the environment. They see a strong connection between their personal health and the health of the environment around them (Urh, 2015). Such consumers like to contribute simultaneously to both their personal health and the environment through their choices regarding shopping and habits (Derryberry, 2019).

Individualism is expressed in the pursuit of new products, in following new trends and in brand loyalty (Szakály et al., 2017). LOHAS users first become aware of products such as green dry cleaning, organic food and alternative health therapies, and then try them out, adopt them, become loyal customers and influence their families and friends (Howard, 2007). They may prefer expensive and luxury brands, while being environmentally aware (Ergüven \& Yilmaz, 2016). Ethical values are associated with different forms of social responsibility (Szakály et al., 2017). These consumers recognize the contribution and responsibility of individuals towards society, and show their support for business practices that apply ethical principles (Schüpbach et al., 2008).

Thus, LOHAS consumers strive to integrate healthier and more sustainable options into all aspects of their lives. Some of the products and services these consumers choose to adhere to their values include the following (Baker \& Bez, 2007, p. 4):

- Food and nutrition - for example: organic and natural foods, vitamin supplements.

- Thoughts and body - yoga, meditation, personal development.

- Home life - natural cleaning products, efficient appliances, recycled paper.

- Buildings and energy - water tanks, solar hot water, green energy.

- Transportation and travelling - low impact of travel, eco tourism.

- Business and money - socially responsible investment, green loans. 


\section{The LOHAS market size}

Paterson (2008) states that in developed countries even 25\% of consumers make environmental and ethical purchasing decisions. According to recent data, it is estimated that there are more than 150 million LOHAS consumers worldwide, and that this market is worth more than $\$ 750$ billion (Mobium Group, 2017). The LOHAS concept of life is mainly related to Western countries, but this trend has expanded and now includes consumers from Asia (Aue, 2008). According to Schulz (2008), LOHAS consumers in Europe represent $18 \%$ of the population, which is around 130 million people. Cohen (2007) and Ramirez (2013) estimate that in the United States this segment represents $23 \%$ of the population, or about 50 million adults. In Japan, a survey conducted in 2005 showed that LOHAS is characteristic of $29 \%$ of the population, or about 37 million people (LOHAS Groupsite, 2019). In New Zealand, this consumer group represents 33\% of the population, while Australia has almost 4 million LOHAS consumers (Paterson, 2008). Starting in 2005, LOHAS has been also becoming widespread in China. Taking into consideration the connection of the LOHAS concept and the philosophy of Chinese culture to the concept of health, sustainability and emotional well-being, it was expected that such a concept would be widely accepted among Chinese consumers (Kan, 2010).

\section{LOHAS consumers and Tourism}

Ergüven \& Yilmaz (2016) state that social benefits, as one of the values LOHAS consumers struggle for, according to the structural and functionalist point of view, can be obtained as a result of tourism activities. Thanks to this segment, the demand for eco-friendly and sustainable tourism trips is growing. LOHAS tourists are characterized by high purchasing power, use of smart technology, interests for cultural travel and experiences, short trips and active vacations (Danube Competence Center, 2015). Compared to other tourists, LOHAS tourists spend even $50 \%$ more money during their stay at the tourist destination and have a longer stay at the destination (one to two weeks) (Northflash, 2017). Considering the percentage of consumers who adopt healthy and sustainable lifestyles, as well as the role they can have in economic development and socio - cultural communication, even in relatively underdeveloped regions, this is considered to be a very profitable tourist segment. Therefore, many tourist destinations have to diversify their tourism products and services if they are to attract this group of consumers (Ergüven \& Yilmaz, 2016).

LOHAS consumers are emerging as an attractive target group in the context of gastronomy and wine tourism (Ergüven \& Yilmaz, 2016). Also, ecotourism, which emerged from the environmental movement, presents one of the biggest market sectors in LOHAS (Urh, 2015). Eco-tourism revenue in the United States in 2002 was estimated at about $\$ 77$ billion (Shum, 2007). More recently, the term eco-tourism, which meant a combination of nature touring and sustainable management, has been expanded to incorporate a focus on indigenous populations and the needs of local communities (Urh, 2015).

One example of good tourism sustainable development practice, directed primarily to attracting LOHAS tourists, is the Xiao Xitou area located in Taipei, China. In order to 
differentiate this area as a tourist destination for LOHAS tourists, they have enriched their offer with various activities and contents adapted to this market segment. In order to promote the cultural and tourism industry and the development of LOHAS recreation and tourism, some of the following projects have been launched (Taipei City Government, 2013, pp. 235-239):

\section{Baishihu Recreation Farm}

After four years of development and investment undertaken by the Taipei City Government, Strawberry Park, as one of the attractions of this district, has been transformed into a multifunctional recreational farm. The Baishihu area characteristics Suspension Bridge, an ecological wetland, an agricultural fish pond and other interesting places along the Wishing Trail are connected within this project. In this way, an interesting itinerary is created for visitors, and they are given the opportunity to explore this rural beauty on foot. At the same time, this project also solved traffic problems in this area. In a short time this place has become one of the main resting areas for the city residents.

\section{Tieguanyin and Nankang Baozhong teas}

Taipei, as an area known for its high quality tea industry such as Tieguanyin and Nankang Baozhong, hosts a competition and exhibitions that are organized by DOED every spring and winter. This event represents both an opportunity to promote this industry and an opportunity to earn extra money. During these events, the Taipei Tea Promotion Center offers tea promotion classes and free guide services of tea culture and organized tea culture camps, as well as other events, and in that way making additional income for tea growers (about 20 million dollars of additional revenue).

\section{Mountain trails}

Taipei mountain trails, used by early settlers to transport coal, fish, tea, and other products, or made as temporary trails for forestry, mining, highway development, and similar, have persisted over the years. One of the key projects undertaken to improve the environment is connected to one of these trails (Huangxi Hot Spring Trail). The work on this trail was completed in 2012, and the final result of the project was the creation of a 600 -meter-long route that combines natural and cultural landmarks. The route follows a natural water stream with rich wildlife. Visitors can enjoy the beauty of nature from a short distance, take a relaxing stroll and enjoy a true eco-trip.

\section{A bike path on river bank}

There are six major routes for cyclists in Taipei. In February 2012, two birdwatching pavilions were built along the riverfront along the Shezi Island bike path, providing places where walkers can enjoy local bird activities, crabs swinging their claws and other animal as well as plant species, typical for the area. In order to expand public recreation and recreation options on the river bank, in September 2012, a "3D Tamsui River Activation Information System" was launched. This system uses up to date technology and integrates water conservation and recreation facilities. The site has six main modules: panoramic shots, panoramic photos, 3D models, graphic profiles of Taipei and rivers, as well as recreational activities. Also, there are 10 bicycle rental stations for recreation. The stations rent different bikes and allow customers to return the bikes to any station in the system. 


\section{Conclusion}

By raising awareness of the need for environmental protection and the dangers caused by actions that are not in accordance with the principles of sustainability, many companies, as well as individuals, become aware of the impact they have on the environment. Tourism and the environment are interconnected, and environmental protection is therefore fundamental to the future development of tourist destinations.

The motivation of contemporary tourists is increasingly connected to destinations that are guided by the principles of sustainable development (Slavković, 2015). Tsuk (2017) states that sustainability should not be viewed as a criterion for choosing a tourist destination. He points out that criteria are made by price, attractions and location, while sustainability is a key reason why guests return to their destination.

Taking into consideration the current situation, the Natural Marketing Insitute (NMI) (2008) considers that concerns for sustainability will not be reduced in the coming period. Although this market and its consumers have been undervalued and often characterized as "Monsters of the new age or radicals" (Urh, 2015), most market experts perceive the LOHAS market as opportunistic, and believe that this trend will continue in the future (Horx, Huber, Steinle, \& Wenzel, 2007; Kotler, 2011; Heim, 2011; Korhonen, Jokinen, \& Joutsela, 2014; Urh, 2015).

After reviewing the literature and considering all the characteristics of LOHAS consumers, it can be concluded that they represent the future of further tourism development. First, because of their principles and efforts to protect the environment, they incorporate sustainable behavior in all aspects of life. Then, this lifestyle means higher expenditures, so this group consists mostly of consumers of higher solvency who are willing to spend more money to maintain their lifestyles. Besides, taking into consideration that the issue of sustainability is being mentioned more often and is becoming a growing problem, it can be expected that an increasing number of tourists will join this group. With the growth of this segment, it can be expected that there will be an increase in the number of destinations and companies that direct their business towards attracting and meeting the needs of this particular tourism segment. Based on the Xiao Xitou case study, it can be seen that destinations as well as different businesses can have many benefits from adapting to the lifestyle of LOHAS tourists.

\section{References}

Aue, S. (2008). Lifestyle of Health and Sustainability (LOHAS): Eine neue Form politischer Partizipation. Munich, Germany: Grin Verlag.

Baker, A., \& Bez, N. (2007). Living LOHAS Consumer Trends Report. Melbourne, Australia: Mobium.

Buerke, A., Straatmann, T., Lin-Hi, N., \& Müller, K. (2017). Consumer awareness and sustainability-focused value orientation as motivating factors of responsible consumer behavior. Review of Managerial Science, 11(4), 959-991.

Cohen, M. J. (2007). Consumer credit, household financial management, and sustainable consumption. International Journal of Consumer Studies, 31(1), 57-65. 
Danube Competence Center. (2015). Sustainable Tourism Major Market Trends and Segments. Retrieved October 20, 2019, from https://www.europarl.europa.eu/ cmsdata/81199/Danube\%20CC_Camernik.pdf

Derryberry, J. (2019). Are You Living LOHAS. Retrieved September 20, 2019, from https://experiencelife.com/article/are-you-living-lohas/

Ergüven, M., \& Yilmaz, A. (2016). The first glocal lifestyle "LOHAS“: a study in Thrace. The Journal of Academic Social Science Studie, 51, 265-275.

Font, X., \& Epler Wood, M. (2007). Sustainable tourism certification marketing and its contribution to SME market access. In R. Black \& A. Crabtree (Eds), Quality Assurance and Certification in Ecotourism, (pp. 147-163). Wallingford, UK: CABI.

Gajić, T., Vujko, A., Penić, M., Petrović, M. D., \& Mrksa, M. (2017). Significant involvement of agricultural holdings in rural tourism development in Serbia. Ekonomika poljoprivrede, 64(3), 901-918.

Grunert, S. C., \& Juhl, H. J. (1995). Values, environmental attitudes, and buying of organic foods. Journal of Economic Psychology, 16(1), 39-62.

Headwaters MB. (2016). LOHAS Lifestyle of Health and Sustainability goes mainstream. Denver, US: Headwaters.

Heim, J. (2011). LOHAS. Or: The Consumption of Sustainability. Freiburg: University of Freiburg. Retrieved October 12, 2019, from http://www.megforum.unifreiburg.de/SOE\%202012\%20papers/Lohas

Horx, M., Huber, J., Steinle, A., \& Wenzel, E. (2007). Zukunft machen: Wie Sie von Trends zu Business-Innovationen kom-men. Frankfurt: Ein Praxis-Guide.

Howard, B. (2007). LOHAS consumers are taking the world by storm. Total Health, 29(3), 58.

Ivanović, V., Gašić, M., Perić, G., \& Krulj - Mladenović, M. (2016). Zeleni turizam kao deo zelene ekonomije u funkciji buduće održivosti. Ecologica, 23(81), 790-794.

Kan, J. (2010). An Environmentally Friendly China?. Global Cosmetic Industry, 178(4), 40-45.

Korhonen, V., Jokinen, S., \& Joutsela, M. (2014). Is Your Package Pro-LOHAS? Findings of the Finnish LOHASPACK study 2011-2014. Helsinki, Finland: Association of Packaging Technology and Research (PTR).

Kotler, P. (2011). Reinventing Marketing to Manage the Environmental Imperative. Journal of Marketing, 75(4), 132-135.

Kreeb, M., Motzer, M., \& Schulz, W. F. (2009). LOHAS als Trendsetter für das Nachhaltigkeitsmarketing. In: C. Schwender, W. Schulz \& M. Kreeb (Eds), Medialisierung der Nachhaltigkeit. Das Forschungsprojekt Balance (f): Emotionen und Ecotainment in den Massenmedien (pp. 303-314). Marburg, Germany.

LOHAS Groupsite. (2019). Welcome to the Groupsite for LOHAS (Lifestyles of Health and Sustainability). Retrieved September 30, 2019, from http://lohas.groupsite. $\mathrm{com} / \mathrm{main} /$ summary 
Mobium Group. (2017, October). LOHAS The Biggest Market You've Never Heard of. Presented at the 2017 National Olive Industry Conference, Albury, Australia.

Natural Marketing Institut (NMI). (2008). Understanding the LOHAS Market Report. Harleysville, US: Natural Marketing Institute.

Northflash. (2017). LOHAS: The biggest market you have never heard of. Retrieved October 20, 2019, from https://northflash.com/lohas-the-biggest-market-youhave-never-heard-of/

Paterson, K. (2008). A new level of consciousness. NZ Business, 22, 28-29.

Pesek, T., Helton, L., \& Nair, M. (2006). Healing across Cultures: Learning from Traditions. EcoHealth, 3(2), 114-118.

Ramirez, E. (2013). The Consumer Adoption of Sustainability-Oriented Offerings: Toward a Middle-Range Theory. Journal of Marketing Theory and Practice, 21(4), 415-428.

Ray, P. H., \& Anderson, S. R. (2000). The cultural creatives: How 50 million people are changing the world. NY: Three Rivers Press.

Schulz, W. F. (2008, December). Der Markt für nachhaltige Produkte, Eine Chance für den Mittelstand. Paper presented at Rahmen der BMZ/DIHK Auftakveranstaltung „Mittelstand schaft Werte”, Berlin, Germany.

Schüpbach, S. S., Gröli, M., Dauwalder, P, \& Amhof, R. (2008). LOHAS. Lifestyle Of Health And Sustainability. London, UK: Ernst \& Young.

Shum, K. (2007). Green Travel: Trends in Ecotourism. Retrieved November 30, 2017, from http://www.lohas.com/green-travel

Slavković, V. (2015). Turističko poslovanje. Visoka turistička škola strukovnih studija, Beograd.

Szakály, Z., Popp, J., Kontor, E., Kovács, S., Pető, K., \& Jasák, H. (2017). Attitudes of the Lifestyle of Health and Sustainability Segment in Hungary. Sustainability, 9(10), 1763.

Štetić, S., \& Trišić, I. (2018). The role and importance of ecosystems in creating tourism activities. Menadžment u hotelijerstvu i turizmu, 6(2), 35-46.

Taipei City Government. (2013). Taipei Yearbook 2013. Taipei City, Taiwan: Taipei City Government.

Tsuk, A. (2017). Interview with Alexandre Tsuk on Tourism Sustainability in Bali and Responsible Travel Trends. Retrieved October 10, 2019, from https:// sustainability-leaders.com/interview-alexandre-tsuk/

Urh, B. (2015), Lifestyle of health and sustainability - the importance of health consciousness impact on LOHAS market growth in ecotourism. Quaestus multidisciplinary research journal, 6, 167-177. 